\title{
PENGARUH FORMULA IKAN HARUAN PADA ANAK PENDERITA GIZI BURUK (DI PUSKESMAS BERANGAS KABUPATEN BATOLA KALSEL)
}

\author{
1,2MAGDALENA, MAHPOLAH \\ 1,2Politeknik Kementerian Kesehatan Banjarmasin \\ Email : lenarere@yahoo.co.id, mahpolah@ymail.com
}

\begin{abstract}
ABSTRAK : Anak-anak merupakan penderita gizi buruk terbesar diseluruh dunia. Untuk mencapai sasaran Millenium Development Goals (MDG) yakni 15,5\% angka prevalensi gizi buruk secara nasional harus diturunkan (Almawaddah,2016). Berdasarkan data Riskesda 2013, Kasus gizi buruk di Kalimantan Selatan adalah 8,2\%, gizi kurang 19,2\%. Angka tersebut menunjukkan kasus gizi buruk di Kalimantan Selatan masih tinggi, termasuk Kabupaten Batola. Data gizi buruk di Puskesmas Berangas Kecamatan Alalak Kabupaten Barito Kuala sampai dengan bulan Juni tahun 2016 adalah : gizi buruk 1 orang (0,045\%), Balita BGM (bawah garis merah) 73 balita $(3,3 \%)$ dan yang dirawat di TFC (Therapeutic Feeding Center) sebanyak 6 orang. Tujuan penelitian ini apakah ada pengaruh formula ikan haruan terhadap cita rasa dan asupan kalori serta protein pada anak penderita gizi buruk di Puskesmas Berangas Kabupaten Batola Kalsel

Jenis penelitian yang dilakukan adalah penelitian eksperimen, penelitian ini menggunakan satu kelompok dengan dua kali perlakuan. Penelitian dilaksanakan di Puskesmas Berangas Kecamatan Alalak Kabupaten Barito Kuala Kalimantan Selatan. Subjek penelitian sebanyak 20 orang, dengan kriteria balita gizi buruk atau balita BGM yang 2 kali berturut-turut tidak naik timbangan berat badannya. Analisis yang menggunakan wilconxon test dengan taraf signifikansi yang digunakan adalah $\mathrm{p}<0,05$.

Hasil peneliian ini adalah : Tidak ada perbedaan antara asupan kalori dan protein yang mendapat formula kentang dengan ikan haruan dengan formula kentang dengan ayam.
\end{abstract}

Kata Kunci : cita rasa, asupan kalori dan zat protein

Copyright (C) 2019 Jurnal Skala Kesehatan. Politeknik Kesehatan Banjarmasin All rights reserved

\section{Corresponding Author:}

magdalena,

Poltekkes Kemenkes Banjarmasin Jurusan Gizi

Jln H. Mistar Cokrokusumo Banjarbaru

Email : lenarere@yahoo.co.id 
ABSTRACT: Children are the biggest sufferers of malnutrition throughout the world. To achieve thetarget of Millennium Development Goals (MDG)15.5\%, the national prevalence of malnutrition must be reduced (Almawaddah, 2016). Based on the 2013 Riskesda data, cases of malnutrition in South Kalimantan were 8.2\%, malnutrition 19.2\%. This figure shows that cases of malnutrition in South Kalimantan are still high, including Kabupaten Batola. Malnutrition data in the Berangas Health Center in Alalak Subdistrict, Barito Kuala Regency up to June 2016 were: 1 malnutrition $(0.045 \%)$, Toddler BGM (under the red line) 73 toddlers $(3.3 \%)$ and those treated in TFC (Therapeutic Feeding Center) as many as 6 people. The purpose of this study is whether there is an influence of fragrant fish formula on taste and caloric and protein intake in children with malnutrition in an outpatient health center in the district of South Kalimantan Batola. The

type of research conducted was experimental research, this study used one group with two treatments. The study was conducted at Berangas Health Center, Alalak Sub-District, Barito Kuala District, South Kalimantan. The research subjects were 20 people, with criteria for malnourished children under five or under-five BGM who did not increase their weight scales twice. The analysis using the Wilconxon test with the significance level used was $p<0.05$.

The results of this study are: There is no difference between calorie intake and protein that gets potato formula with fragrant fish with potato formula with chicken.

\section{Keywords: taste, calorie intake and protein substances}

\section{PENDAHULUAN}

Indonesia sebagai salah satu negara berkembang masih menghadapi masalah gizi yang cukup besar. Kurang gizi pada balita terjadi karena pada usia tersebut kebutuhan gizi lebih besar dan balita merupakan tahapan usia yang rawan gizi. Kurang Energi dan Protein (KEP) adalah kurang gizi yang disebabkan rendahnya angka konsumsi energi dan protein dalam makanan sehari-hari, sehingga tidak memenuhi Angka Kecukupan Gizi (AKG).

KEP merupakan salah satu masalah gizi utama yang banyak dijumpai pada balita di Indonesia maupun negara berkembang lainnya. KEP berdampak terhadap pertumbuhan, perkembangan intelektual dan produktivitas antara $20-30 \%$, selain itu juga berdampak langsung terhadap kesakitan dan kematian. (Kemenkes, 2011).

Anak-anak merupakan penderita gizi buruk terbesar diseluruh dunia. Dilihat dari segi wilayah, lebih dari $70 \%$ kasus gizi buruk pada anak didominasi Asia, sedangkan $26 \%$ di Afrika dan 4\% di Amerika Latin. Berdasarkan Riskesda 2013 terdapat 19,6\% kasus balita kekurangan gizi dan jumlah tersebut terdidri dari 5,7\% balita dengan gizi buruk. Angka tersebut meningkat dibandingkan dengan data Riskesda 2010 sebesar 17,9\% dan Riskesda 2007 sebesar 18,4\%. Untuk mencapai sasaran Millenium Development Goals (MDG) yakni 15,5\% angka prevalensi gizi buruk secara nasional harus diturunkan (Almawaddah,2016).

Berdasarkan data Riskesda 2013, Kasus gizi buruk di Kalimantan Selatan adalah 8,2\%, gizi kurang 19,2\%. Angka tersebut menunjukkan kasus gizi buruk di Kalimantan Selatan masih tinggi, dan dua kabupaten yang termasuk prevalensi gizi buruk adalah Kabupaten Hulu Sungai Selatan dan Kabupaten Batola. Data gizi buruk di Puskesmas Berangas Kecamatan Alalak Kabupaten Barito Kuala sampai dengan bulan Juni tahun 2016 adalah : gizi buruk 1 orang $(0,045 \%)$, Balita BGM (bawah garis merah) 73 balita (3,3\%) dan yang dirawat di TFC (Therapeutic Feeding Center) sebanyak 6 orang. Kasus ini meningkat dibandingkan dengan data tahun 2015, kasus gizi buruk 1 orang $(0,045 \%)$, balita BGM 53 orang $(2,31 \%)$ dan tidak ada yang dirawat di TFC.

Melihat angka prevalensi gizi buruk dan kurang di Indonesia serta pengaruhnya yang begitu tinggi dalam tumbuh kembang anak, pemerintah memasukkan program perbaikan gizi ke 
dalam salah satu program pokok puskesmas. Berbagai upaya untuk menghadapi permasalahan gizi di Indonesia saat ini antara lain melalui revitalisasi Posyandu dalam meningkatkan cakupan penimbangan balita, penyuluhan dan pendampingan, pemberian makanan pendamping ASI (MPASI) atau pemberian makanan tambahan (PMT), peningkatan akses dan mutu pelayanan gizi melalui tatalaksana gizi buruk di puskesmas perawatan dan rumah sakit, penanggulangan penyakit menular dan pemberdayaan masyarakat melalui keluarga sadar gizi (Kemenkes,2011).

Terapi gizi pada anak gizi buruk mempunyai peranan yang sangat penting untuk mempercepat penyembuhan penyakit. Kesalahan pemberian makanan akan memperlambat penyembuhan penyakit. Kelebihan maupun kekurangan pemberian makan dapat memperburuk kondisi anak, bahkan dapat menyebabkan kematian. Oleh karena itu harus diberitahukan kepada orang tua tentang hak pasien dalam perawatan dan pemberian makan anak gizi buruk. Terapi gizi untuk penderita gizi buruk diterapkan dalam beberapa fase yaitu : fase stabilisasi, fase transisi dan fase rehabilitasi (Kemenkes,2011).

Penelitian mengenai formula makanan yang dimodifikasi seperti formula kentang, formula tempe, formula ayam dan tahu, formula kacang hijau, formula ikan dan modifikasi makanan lainnya juga diberikan. Pada penelitian Amelia dkk, 2014 menyatakan bahwa rerata asupan energi meningkat secara signifikan mendekati jumlah yang dianjurkan $150-220 \mathrm{kkal}$ yang diberikan formula $F 75$ dan formula F 100 dalam kemasan sachet serta paket makanan lain pada anak gizi buruk dalam program pemulihan rawat jalan. Begitu pula penelitian S.Suwarti, 2013 menyatakan bahwa pemberian paket pemberian makanan tambahan kepada penderita gizi buruk sebanyak $30-50 \%$ berubah status gizinya untuk pemberian paket pemulihan selama 6 bulan dengan 13 kali kunjungan.

Berbagai penelitian untuk meningkatkan status gizi pada penderita gizi buruk telah yang menambahkan ekstrat ikan gabus sudah banyak dilakukan, antara lain penelitian Syafaini, 2007, dengan memberikan ekstrak ikan gabus yang mempunyai kandungan albumin yang tinggi bisa membantu meningkatkan kadar albumin pada penderita gizi buruk yang kadar albuminnya rendah dibawah $2,5 \mathrm{mg} \%$. Penelitian lain juga melaporkan bahwa penggunaan ikan gabus sebagai sumber protein ternyata dapat mempertahankan nilai albumin penderita rawat inap di rumah sakit sehingga dapat membantu mempercepat proses penyembuhan pasien (Syarfaini, 2007).

Penelitian serupa dari Kusumawardhani, 2004, mengenai pemberian diet formula tepung ikan gabus pada penderita sindrom nefrotik menyatakan ada perbedan nilai albumin awal dan nilai albumin pada kedua kelompok. Penelitian lain mengenai formula ikan gabus juga dilakukan oleh Dewi, 2014 yang menyatakan bahwa hasil penelitian organoleptik mengenai penerimaan panelis yaitu warna tepung ikan gabus $96,67 \%$, aroma sebesar $63,33 \%$, tekstur $73,33 \%$, dan rasa $58,33 \%$.

Pemberian makanan pada anak gizi buruk adalah formula WHO dan formula modifikasi, sesuai dengan fase menurut berat badan dan umur serta penyakit klinis yang diderita. Formula kentang merupakan formula modifikasi yang bertujuan untuk memberi cita rasa serta nilai zat gizi untuk meningkatkan status gizi. Formula kentang dengan bahan lauk hewani daging ayam dapat dimodifikasi atau diganti menu tersebut sesuai dengan daerah penderita gizi buruk berada. Ikan haruan merupakan lauk hewani yang tinggi protein serta albumin yang dapat membantu sebagai makanan formula untuk anak penderita gizi buruk.

Cita rasa makanan merupakan aspek dari penampilan dan rasa masakan yang dibuat meliputi warna makanan, aroma makanan, tekstur makanan dan rasa makanan (Kemenkes,2013).

Pemberian formula kentang diberikan kepada penderita gizi buruk yang sudah melewati masa stabilisasi dan transisi, formula kentang dapat diberi tambahan sesuai dengan keadaan daerah penderita gizi buruk, dapat diberi tambahan ayam, ikan maupun telur Formula kentang dapat dimodifikasikan dengan menambah ayam, daging maupun ikan. Daging dan ayam termasuk lauk yang mahal untuk daerah kabupaten Batola, sedangkan ikan haruan

Vol.10, No.1, Januari 2019 
mudah di dapat dan tidak selalu harus membeli, bisa dengan menangkap ikan dengan cara tradisional menurut daerah setempat. Ikan gabus diketahui mengandung senyawa- senyawa penting yang berguna bagi tubuh. Protein ikan gabus adalah 25,5\% yang berarti lebih tinggi disbanding ikan bandeng(20,0\%), ikan emas (16,0\%), ikan kakap (20,0\%), maupun ikan sarden $(21, ! \%)$. Kadar albumin ikan gabus lebih tinggi disbanding dengan ikan-ikan tersebut. ( Almatsier, 2008).

Tujuan penelitian ini adalah untuk mengetahui apakah ada pengaruh formula ikan haruan terhadap cita rasa dan asupan kalori serta protein pada anak penderita gizi buruk di Puskesmas Berangas Kabupaten Batola Kalsel

\section{BAHAN DAN METODE}

Pelitian ini adalah penelitian kuasi eksperimen, penelitian ini menggunakan satu kelompok dengan satu kali perlakuan. Lokasi Penelitian dilaksanakan di Puskesmas Berangas Kecamatan Alalak Kabupaten Barito Kuala Kalimantan Selatan. Penelitian ini telah dilakukan

Subjek penelitian adalah balita gizi buruk 20 orang dengan kriteria balita gizi buruk atau balita BGM yang 2 kali berturut-turut tidak naik timbangan berat badannya, 20 orang kader posyandu untuk menilai cita rasa formula. Data responden yang terdiri atas nama ,umur, jenis kelamin. Data tersebut dikumpulkan dengan cara wawancara dan mengisi kuesioner, Data asupan makanan diperoleh dengan cara wawancara menggunakan formulir food recall 2x24 jam selama 2 kali pemberian. Formula Ikan haruan atau ayam adalah modifikasi formula untuk penderita gizi buruk yang terdiri dari bahan makanan : ikan haruan, ayam, kentang, wortel, susu, minyak sayur, gula dan garam

Hasil food recall 2x24jam selama dianalisis dengan menggunakan Nutri2008. Penilaian cita rasa menggunakan kuesioner untuk menilai : warna, aroma, rasa dan tekstur. Uji beda menggunakan t-tes.

\section{HASIL DAN PEMBAHASAN}

Penilai cita rasa adalah kader posyandu yang berjumlah 20 orang, yang merupakan kader berpengalaman pada kegiatan posyandu, semua kader adalah perempuan, dengan tingkat pendidikan paling rendah adalah SLTP dan berumur antara 20 sampai 53 tahun

\section{A. Perbedaan Mengenai Cita Rasa antara Formula Kentang dan Ayam dengan Formula Kentang dan Ikan Haruan}

Hasil uji Organaleptik adalah segi warna untuk formula ikan haruan dengan kentang $100 \%$ responden menyatakan menarik, dan 10\% menyatakan kurang menarik, dari segi aroma $90 \%$ responden menyatakan menarik dan $10 \%$ menyatakan kurang menarik. 


\section{Gambar 1. Diagram Uji Organoleptik Cita Rasa}

\section{Uji Organoleptik "Rasa"}

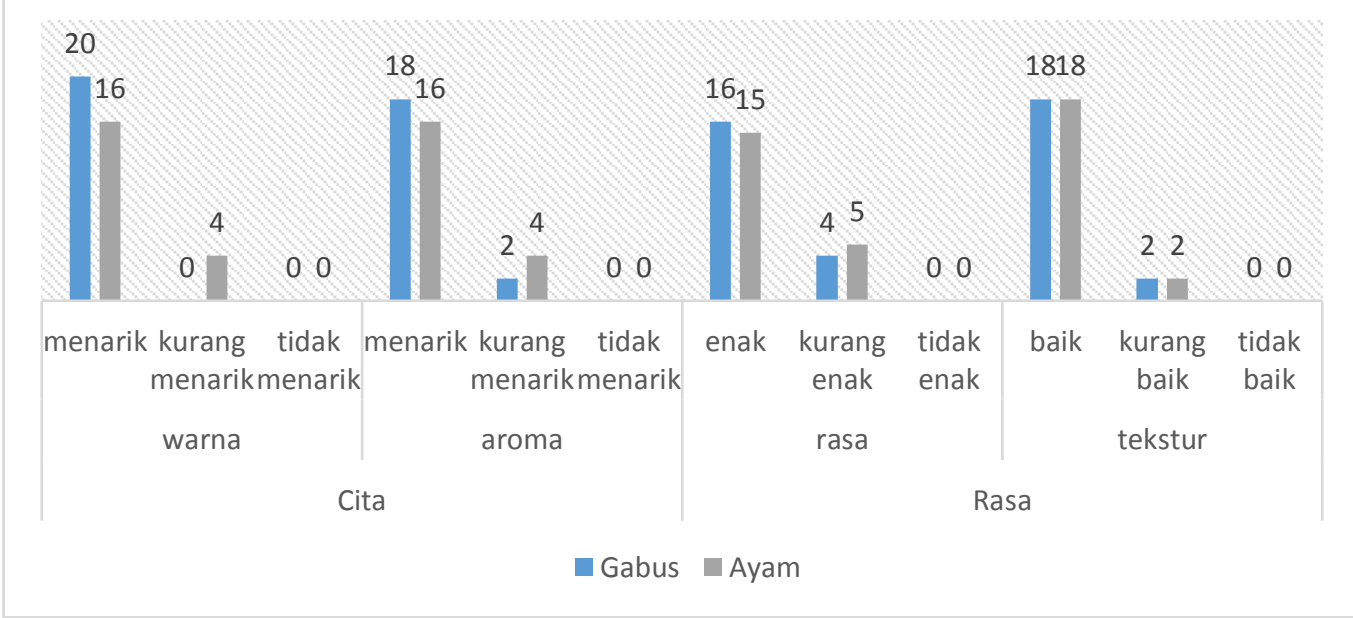

Hasil uji Organaleptik formula ikan haruan dengan kentang adalah segi warna untuk formula ikan haruan dengan kentang 100\% responden menyatakan menarik, dan $10 \%$ menyatakan kurang menarik, dari segi aroma $90 \%$ responden menyatakan menarik dan $10 \%$ menyatakan kurang menarik. Penilaian terhadap rasa adalah $80 \%$ menyatakan enak dan $20 \%$ menyatakan kurang enak, dari segi tektur, $90 \%$ menyatakan baik.

Perbedaan cita rasa formula kentang dengan haruan dibanding dengan formula kentang dengan ayam adalah: dari segi warna semua responden lebih tertarik dengan formula kentang dengan ikan haruan, begitu juga dengan aroma dan rasa, lebih banyak responden menyukai formula kentang dengan ikan haruan, sedangkan untuk tekstur masing-masing menyatakan tekstur kedua formula tersebut adalah baik. Formula kentang dengan ikan haruan lebih baik dari segi warna, aroma dan rasa dibanding formula kentang dengan ayam.

Warna makanan yang menarik disebabkan ada bahan makanan wortel yang mengandung karoten yang dapat menghasilkan warna jingga sampai merah (Novia, DRM, 2010), begitu pula aroma enak disebabkan bahan mengandung susu, karena susu sifatnya dapat menyerap bau amis yang ada pada ikan, rasa enak makanan adalah dari makanan sumber protein yaitu susu dan ikan haruan dan teksturnya lembut karena bahan -bahan untuk formula kentang dengan ikan haruan adalah rendah serat (Cahyo S, 2006). 
2. Perbedaan Asupan Kalori dan Protein yang Mendapat Formula Kentang dengan Ayam dan Formula Kentang dengan ikan Haruan

Tabel 1. Asupan Kalori Formula Kentang degan Ikan Haruan dan Formula Kentang dengan Ayam

\begin{tabular}{|c|c|c|c|c|}
\hline \multirow{3}{*}{ KATEGORI } & \multicolumn{4}{|c|}{ ASUPAN KALORI } \\
\hline & \multicolumn{2}{|c|}{$\begin{array}{l}\text { Formula Kentang dengan } \\
\text { ikan haruan }\end{array}$} & \multicolumn{2}{|c|}{$\begin{array}{l}\text { Formula kentang } \\
\text { ayam }\end{array}$} \\
\hline & $\mathrm{N}$ & $\%$ & $\mathrm{~N}$ & $\%$ \\
\hline Baik & 4 & 20 & 6 & 30 \\
\hline Sedang & 5 & 25 & 5 & 25 \\
\hline Kurang & 4 & 20 & 4 & 20 \\
\hline Defisit & 7 & 35 & 5 & 25 \\
\hline Jumlah & 20 & 100 & 20 & 100 \\
\hline
\end{tabular}

$P=0,206: p>0,05$

Asupan kalori yang mendapat formula kentang dengan ikan haruan yang banyak adalah kategori defisit yaitu $35 \%$ dan yang kategori baik 20\%, sedangkan asupan kalori yang mendapat formula kentang dengan ayam yang banyak adalah kategori baik yaitu $30 \%$, sedang kategori defisit $25 \%$. Jumlah kalori dalam 100 gram ikan haruan adalah 74 kalori, sedangkan ayam dalam 100 gram mengandung 302 kalori

Berdasarkan uji statistik, $p=0,206$ artinya tidak ada perbedaan yang signifikan antara tingkat asupan konsumsi energi formula kentang dan ikan haruan dengan formula kentang dan ayam.

Tabel 8. Asupan Protein Formula Kentang degan Ikan Haruan dan Formula Kentang dengan Ayam

\begin{tabular}{|c|c|c|c|c|}
\hline \multirow{3}{*}{ KATEGORI } & \multicolumn{4}{|c|}{ ASUPAN PROTEIN } \\
\hline & \multicolumn{2}{|c|}{$\begin{array}{l}\text { Formula Kentang dengan } \\
\text { ikan haruan }\end{array}$} & \multicolumn{2}{|c|}{$\begin{array}{l}\text { Formula kentang dengan } \\
\text { ayam }\end{array}$} \\
\hline & $\mathrm{N}$ & $\%$ & $\mathrm{~N}$ & $\%$ \\
\hline Baik & 12 & 60 & 16 & 80 \\
\hline Sedang & 4 & 20 & 1 & 5 \\
\hline Kurang & 4 & 20 & 1 & 5 \\
\hline Defisit & 0 & 0 & 2 & 10 \\
\hline Jumlah & 20 & 100 & 20 & 100 \\
\hline
\end{tabular}

$P=0,739: p>0,05$

Asupan protein yang mendapat formula kentang dengan ikan haruan yang banyak adalah kategori baik yaitu $60 \%$ dan tidak ada yang kategori defisit, sedangkan asupan protein yang mendapat formula kentang dengan ayam yang banyak adalah kategori baik yaitu $80 \%$, sedang kategori defisit 10\%. Jumlah protein dalam 100 gram ikan haruan adalah 18,2 gram, sedangkan ayam dalam 100 gram mengandung 25,2 gram

Berdasarkan uji statistik, $\mathrm{p}=0,739$ artinya tidak ada perbedaan yang signifikan antara tingkat asupan konsumsi protein formula kentang dan ikan haruan dengan formula kentang dan ayam.

Perbedaan jumlah kalori antara ayam dengan ikan haruan nilainya lebih besar, lebih banyak kalori ayam dibanding ikan haruan yaitu 284 kalori ayam dan 70 kalori ikan haruan, untuk menambah jumlah kalori dapat menambahkan dengan bahan makanan pokok seperti tepung beras, sehingga formula kentang dengan ikan haruan dapat menambah jumlah kalori tersebut. Gizi kurang pada anak sehingga kurus terjadi karena kurang zat sumber tenaga. Karbohidrat memegang peranan penting sebagai sumber energy utama bagi manusia. Semua karbohidrat berasal dari tumbuh-tumbuhan, kentang merupakan sumber karbohidrat dengan nilai kalori 83

Vol.10, No.1, Januari 2019 
kalori dalam 100 gram nya ( Almatsier, 2005). Formula kentang dengan ikan haruan dapat ditambah dengan tepung beras sehingga meningkatkan jumlah kalori yaitu 364 kalori dalam 100 gram tepung beras.

Perbedaan jumlah protein antara ayam dan ikan haruan sangatlah besar, lebih banyak protein ikan haruan dibanding ayam, begitu juga jumlah albumin lebih besar pada ikan haruan.

Protein mempunyai fungsi khas yang tidak dapat digantikan oleh zat gizi lain, yaitu membangun serta memelihara sel-sel jaringan tubuh (Almatsier, 2005).

Ikan haruan yang merupkan sumber protein dan juga merupakan sumber albumin yang baik dapat membantu pemulihan pada penderita gizi buruk. Kekurangan albumin bisa menyebabkan zat gizi tidak bisa di edarkan dengan baik keseluruh tubuh, sehingga bagi anak bisa menyebabkan terhambatnya pertumbuhan dan perkembangan otak yang tidak maksimal, penurunan kekebalan tubuh sehingga menyebabkan anak mudah sakit (Ananya Mandal, 2012).

\section{KESIMPULAN}

1. Cita rasa formula kentang dengan ayam sebagian besar menyatakan warna menarik $80 \%$, aroma enak $80 \%$, rasa enak $75 \%$ dan tekstur baik $90 \%$.

2. Cita rasa formula kentang dengan ikan haruan semua responden Menyatakan semua warna menarik $100 \%$, aroma enak $90 \%$, rasa enak $80 \%$ dan tekstur baik $90 \%$

3. a. Formula kentang dengan ikan haruan lebih baik cita rasanya dari Segi warna, aroma dan rasa dibanding formula kentang dengan ayam.

b. Tidak ada perbedaan antara asupan kalori dan protein yang mendapat formula kentang dengan ikan haruan dan formula kentang dengan ayam.

\section{SARAN}

Penelitian ini dapat menjadi pedoman untuk mendemotrasikan pada ibu balita cara pembuatan formula kentang dengan ikan haruan dan dapat dilakukan di Puskesmas yang ada TFC nya.

\section{DAFTAR PUSTAKA}

1. Amelia, 2013. dkk. Pemulihan Gizi Buruk Rawat Jalan memperbaiki asupan energi dan status gizi pada anak usia dibawah tiga tahun. Jurnal Gizi Klinik Indonesia (The Indonesian Journal of Clinical Nutrition) IJCN, P3GM, Bogor.

2. Ananya Mandal, 2012. http://www.ncbi.nlm.nih.gov/pubmedhealt/ diakses 28 Agustus 2017

3. Cahyo Saparinto, 2006. Bahan Tambahan Pangan. Karnisius

4. Depkes RI, 2009. Buku Bagan dan Petunjuk Teknis Tatalaksana Anak Gizi Buruk

5. Depkes RI, 2009. Buku Pemantauan Tatalaksana Anak Gizi Buruk

6. Dewi, 2014. Uji Organoleptik Formula Biskuit Fungsional Berbasis Tepung Ikan Gabus (Ophiocephalus striatus) (The Organoleptic Fungtional Biscuit Furmulation Based on Snakehead Fish (Ophiocephalus striata) Flour,Jurnal Teknologi Pertanian Agritech UGM, Vol 34, No. 02.

7. Diah Krisnansari, Nutrisi dan Gizi Buruk. Mandala of Health, Volume 4, No I, Januari .2010

8. Kementerian Kesehatan RI, 2010. Draft Pedoman Pelayanan Anak Gizi Buruk

9. Kementerian Kesehatan RI, 2011. Keputusan Menteri Kesehatan RI, No 1995/Menkes/SK/XII/2010. Tentang Standar Antropometri Penilaian Status Gizi Anak

10. Kementerian Kesehatan RI, 2011. Pedoman Penyelenggaraan Training ofTainer (TOT) Tatalaksana Anak Gizi Buruk

11. Kementerian Kesehatan RI, 2013. Bagan Tatalaksana Anak Gizi Buruk 
Buku I

12. Kementerian Kesehatan RI, 2013. Bagan Tatalaksana Anak Gizi Buruk Buku II

13. Kusumawardani. Pemberian Diet Formula Tepung Ikan Gabus (Ophiocephalus striatus) Pada Penderita Sindom Nefrotik.Tesis UNDIP. 2004.

14. http//almawaddah.wordpress.com/2016/06/06/Cara Mendeteksi Gizi Buruk pada Balita

15. http// dinkes.jatimpov.go.id/userimage2016/09/09/ TFC (Therapeutic Feeding Center/PPG

16. http//blogspot.co.id/informasi kesehatan \& kedokteran/2011

17. Moehji Sjahmien, 1992. Penyelenggaraan Makanan Institusi dan Jasa Boga. Jakarta. Bharata Karya Aksara

18. Moehji Sjahmien, 1992. Penyelenggaraan Makanan Institusi dan Jasa Boga. Jakarta. Bharata Karya Aksara

19. Novia, DRM. 2010. Mewaspadai Pewarna Makanan. http//www.miror.unpad. Ac.id.akses 28 agustus 2018.

20. Riset Kesehatan Dasar Tahun 2013

21. Suwarti, 2013. Pemulihan Gizi Buruk Secara Rawat Jalan di Puskesmas. Jurnal Gizi Klinik Indonesia (The Indonesian Journal of Clinical Nutrition) IJCN, P3GM, Bogor. 